\title{
Cytotoxic and Apoptotic Effects of Different Extracts of Artemisia turanica Krasch. on K562 and HL-60 Cell Lines
}

\author{
Zahra Tayarani-Najaran, ${ }^{1}$ Mahla Sareban, ${ }^{1,2}$ Atefeh Gholami, ${ }^{1,2}$ \\ Seyed Ahmad Emami, ${ }^{2}$ and Mahdi Mojarrab ${ }^{3}$ \\ ${ }^{1}$ Department of Pharmacodynamics and Toxicology, School of Pharmacy, Mashhad University of Medical Sciences, \\ Mashhad 9188617871, Iran \\ ${ }^{2}$ Department of Pharmacognosy, School of Pharmacy, Mashhad University of Medical Sciences, Mashhad 9188617871, Iran \\ ${ }^{3}$ Novel Drug Delivery Research Center, School of Pharmacy, Kermanshah University of Medical Sciences, \\ Kermanshah 6734667149, Iran
}

Correspondence should be addressed to Mahdi Mojarrab; mahdi.mojarab@gmail.com

Received 23 August 2013; Accepted 11 September 2013

Academic Editors: J. M. Nesland and D. Noonan

Copyright (c) 2013 Zahra Tayarani-Najaran et al. This is an open access article distributed under the Creative Commons Attribution License, which permits unrestricted use, distribution, and reproduction in any medium, provided the original work is properly cited.

\begin{abstract}
Artemisia is an important genus of Iranian flora. Cytotoxic activities for some species of the genus have already been reported. In this study, we have investigated the cytotoxic effects of $n$-hexane, $\mathrm{CH}_{2} \mathrm{Cl}_{2}, \mathrm{EtOAc}, \mathrm{EtOH}$, and EtOH/ $\mathrm{H}_{2} \mathrm{O}(1: 1)$ extracts of $A$. turanica Krasch. on two human leukemic cancer cell lines (K562 and HL-60) and J774 as normal cells using alamarBlue (resazurin) assay. PI staining of the fragmented DNA and western blot analysis were used to evaluate the possible apoptotic effect of the extract. The $\mathrm{CH}_{2} \mathrm{Cl}_{2}$ extract of $A$. turanica showed the most antiproliferative effect on cancer cells among all tested extracts with $\mathrm{IC}_{50}$ values of 69 and $104 \mu \mathrm{g} / \mathrm{mL}$ on K562 and HL-60 cells, respectively, whereas the normal cells were not affected significantly by this extract. Sub-G1 peak in the flow cytometry histogram of the cells treated with $\mathrm{CH}_{2} \mathrm{Cl}_{2}$ extract of $A$. turanica and cleavage of PARP protein confirmed the induction of apoptosis with $\mathrm{CH}_{2} \mathrm{Cl}_{2}$ extract. Taken together, the findings of the present work suggest the anticancer potential of $\mathrm{CH}_{2} \mathrm{Cl}_{2}$ extract of $A$. turanica on human leukemic cancer cell lines.
\end{abstract}

\section{Introduction}

Cancer is a leading cause of life-threatening disease with limited efficient therapies [1]. Considering the significant levels of toxicity and drug resistance of current anticancer regimens, the challenge to develop highly effective drugs with little or no side effects is crucial.

Exploring the anticancer ability of novel compounds including plant derivatives provides a wealthy source of novel and potent bioactive compounds with minimal side effects. Artemisia is a promising natural source of phytochemicals with potent antimalarial and anticancer properties [2-7].

One of the largest genera in the tribe Anthemideae of the Asteraceae (Compositae) is the genus Artemisia, which grows mostly in the temperate zone of Asia, Europe, and North America [8]. There are 43 species of the genus in Iran [9], of which two are endemic [10]. Diverse chemical components in this genus such as flavonoids, coumarins, sterols, polyacetylenes, monoterpenes, sesquiterpenes, and sesquiterpene lactones have been reported so far [11, 12]. Artemisia turanica Krasch. with the Persian name of "Dermaneye ghermez" grows wildly in northeastern Iran [13]. One study has proved the effect of methanol extract of the aerial parts of the plant against Staphylococcus aureus, Bacillus subtilis and Pseudomonas aeruginosa [14]. Major volatiles from the aerial parts of A. turanica were identified as 1,8-cineole, chrysanthenone, and davanone [15]. Antimalarial activity of $A$. turanica during early infection as well as its in vitro leishmanicidal activity has been reported [16-18]. The crude hydroethanolic extract showed moderate toxicity against the HepG2 cell line [19].

In an effort to evaluate the potential anticancer effect of different extracts of $A$. turanica on human cancer cell lines, we have investigated the possible cytotoxic activity of the $n$ hexane, $\mathrm{CH}_{2} \mathrm{Cl}_{2}$, EtOAc, EtOH, and EtOH/H$/ \mathrm{H}_{2} \mathrm{O}(1: 1)$ extracts of $A$. turanica Krasch. on two human leukemic cancer cell lines (K562 and HL-60) and J774 as normal cells. Meanwhile, the possible mechanism(s) of the apoptosis mediated by the plant was also explored. Appearance of the apoptosis related 
protein and cleavage of PARP provided the first evidence that $\mathrm{CH}_{2} \mathrm{Cl}_{2}$ extract of $A$. turanica could induce apoptosis in human leukemia cells.

\section{Methods}

2.1. Reagents and Chemicals. AlamarBlue (resazurin) was obtained from Sigma (Saint Louis, MO, USA); RPMI-1640 and FCS were from Gibco; $\beta$-actin and PARP antibodies, anti-rabbit IgG, and HRP linked antibody were from Cell Signaling technology (Boston, USA); ECL Western blotting detection reagent was from Bio-Rad (USA); the fluorescent probe propidium iodide (PI), protease inhibitor cocktail, phosphatase inhibitor cocktail, sodium citrate, Triton X-100, phenylmethylsulfonyl fluoride, and Bio-Rad Protein Assay Kit (Hercules, CA, USA) were used; all the solvents used for extraction were purchased from Caledon and Scharlau.

2.2. Plant Materials. Aerial parts of the plant were collected from Sami' abad, Torbat Jam (Razavi Khorasan province, Iran) in September 2010. Sample was identified by Dr Valiollah Mozaffarian (Research Institute of Forest and Rangelands, Tehran, Iran). The voucher specimen (no. 12572) has been deposited in the herbarium, Department of Pharmacognosy, School of Pharmacy, Mashhad University of Medical Sciences, Mashhad, Iran.

2.3. Preparation of Extracts and Fractions. Air-dried and ground aerial parts $(150 \mathrm{~g})$ of $A$. turanica were extracted with $n$-hexane (40-60), $\mathrm{CH}_{2} \mathrm{Cl}_{2}$, EtOAc, EtOH, and $\mathrm{EtOH} / \mathrm{H}_{2} \mathrm{O}$ $(1: 1 \mathrm{v} / \mathrm{v})$, respectively (Sequential maceration with ca. $3 \times 1.5 \mathrm{~L}$ of each solvent). The extracts were filtrated with filter paper and dried using rotary evaporator at a reduced pressure at a temperature below $45^{\circ} \mathrm{C}$ to yield $4.21,18.25,0.91,5.94$, and $28.26 \mathrm{~g}$ of each extract, respectively.

All of the isolated extracts were dissolved in dimethylsulfoxide (DMSO) and then were subjected to cytotoxic and apoptosis assays (Figure 1).

2.4. Cell Culture and Treatment Agents. The human leukemic cancer cell lines HL-60 and K562 were obtained from Pasteur Institute (Tehran, Iran) and maintained in RPMI-1640 medium with $10 \% \mathrm{v} / \mathrm{v}$ fetal bovine serum and $100 \mu / \mathrm{mL}$ penicillin and $100 \mathrm{mg} / \mathrm{mL}$ streptomycin at $37^{\circ} \mathrm{C}$ in a humidified atmosphere of $5 \% \mathrm{CO}_{2}$ and $95 \%$ of air.

2.5. In Vitro Cell Proliferation. The AlamarBlue reagent is a cell viability indicator using the reducing power of living cells to quantify the proliferation of various cell lines, bacteria, plant, and fungi that allow to measure cytotoxicity of various chemicals. Upon entering cells, the blue and nonflorescent resazurin converts to the florescent and purple resorufin in viable cells [20].

About $5 \times 10^{4} \mathrm{~K} 562$ and $10^{5}$ HL-60 cells were seeded in each well of 96-microwell plate and treated with various concentrations of each extract of $A$. turanica $(0-200 \mu \mathrm{g} / \mathrm{mL})$. J774 cell line was used as nonmalignant cells. After 48 incubations, $20 \mu \mathrm{L}$ resazurin $(0.01 \% \mathrm{w} / \mathrm{v}$ in PBS $)$ was added to each well,

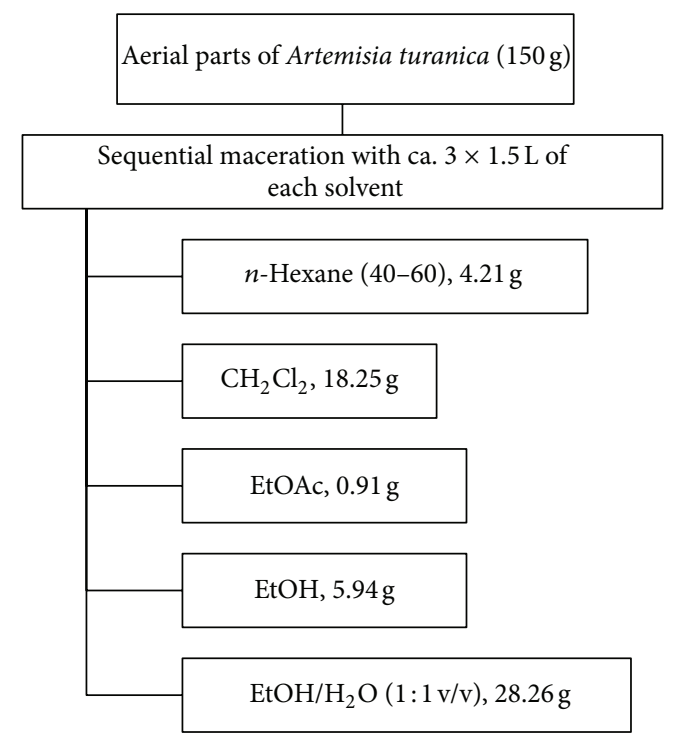

Figure 1: Extraction scheme of $n$-hexane, $\mathrm{CH}_{2} \mathrm{Cl}_{2}$, EtOAc, EtOH, and $\mathrm{EtOH} / \mathrm{H} 2 \mathrm{O}(1: 1)$ extracts of $A$. turanica.

and the plates were incubated at $37^{\circ} \mathrm{C}$ for $4 \mathrm{~h}$ before the absorbance was measured at $570 \mathrm{~nm}$ (test wavelength) and $600 \mathrm{~nm}$ (reference wavelength) in a Synergy H4 Hybrid Multi-Mode Microplate Reader (BioTek, Winooski, USA; Winooski is a city in Chittenden). The cytotoxicity of the $A$. turanica extracts was expressed as $\mathrm{IC}_{50}$, calculated using Prism 5 Software (GraphPad, La Jolla, CA, USA), and presented as mean \pm SEM from three independent experiments (with three replicates for each concentration tested extract). For each study, a control sample remained untreated and received only medium in place of the text materials.

2.6. PI Staining. Apoptotic cells were detected by PI staining of small fragments of DNA in treated cells followed by flow cytometry. It has been reported that following DNA fragmentation the so-called sub-G1 peak can be noticed following incubation of cells in a hypotonic phosphate-citrate buffer containing quantitative DNA-binding dye such as PI. Apoptotic cells that have lost DNA will take up less stain and will show up in the left side of the G1 peak in the histogram. Briefly, $10^{6} \mathrm{~K} 562$ and HL-60 cells were seeded in each well of a 24-well plate and treated with $\mathrm{CH}_{2} \mathrm{Cl}_{2}$ extract of $A$. turanica in different concentrations $(25,50$ and $100 \mu \mathrm{g} / \mathrm{mL})$ for $48 \mathrm{~h}$. Floating and adherent cells were then harvested and incubated at $4^{\circ} \mathrm{C}$ overnight in the dark with $750 \mu \mathrm{L}$ of a hypotonic buffer $(50 \mu \mathrm{g} / \mathrm{mL}$ PI in $0.1 \%$ sodium citrate plus $0.1 \%$ Triton X-100) before flow cytometric analysis using a FACScan flow cytometer (Becton Dickinson, San Diego, CA) was performed. A minimum of $10^{4}$ events were acquired for each sample. All data were then analyzed using WinMDI Version 2.8 software.

2.7. Western Blotting Analysis. About $10^{7} \mathrm{HL}-60$ and $\mathrm{K} 562$ cells were treated with 25,50 , and $100 \mu \mathrm{g} / \mathrm{mL}$ of the $\mathrm{CH}_{2} \mathrm{Cl}_{2}$ extract of $A$. turanica for $48 \mathrm{~h}$. The cells were rinsed and harvested with cool PBS for 3 times; the cell pellet was 
resuspended in a lysis buffer containing $50 \mathrm{mM}$ tris- $\mathrm{HCl}$ (PH 7.4), $150 \mathrm{mM} \mathrm{NaCl,} \mathrm{1 \%} \mathrm{TritonX-100,} 1 \mathrm{mM}$ EDTA, 0.2\% SDS, $1 \%$ Protease inhibitor cocktail, $1 \%$ phosphatase inhibitor cocktail, and $1 \mathrm{mM}$ phenylmethylsulfonyl fluoride and left on ice for $30 \mathrm{~min}$. After centrifugation at $10000 \mathrm{rpm}$ for $20 \mathrm{~min}$ at $4^{\circ} \mathrm{C}$, the cell lysate was collected, and protein concentration was determined according to the Bio-Rad Protein Assay kit. Equal amounts of proteins were subjected to $8 \%$ and $12.5 \%$ SDS-page (W/V). The proteins were transferred to a polyvinylidene fluoride (PVDF) membrane and subjected to immunoblotting using Bax, $\beta$-actin, and PARP antibody as primary antibodies and anti-rabbit IgG and HRP-linked antibody as secondary antibodies; Bax protein band and PARP cleavage in K562 and HL-60 cells were detected by enhanced chemiluminescence using the ECL western blotting detection reagent. Images were quantified using Gel-pro Analyser V.6.0 Gel Analysis software (Media Cybernetics, Inc, Bethesda, MD, USA).

2.8. Statistical Analysis. One way analysis of variance (ANOVA) and Bonferroni post hoc test were used for data analysis. All the results were expressed as mean \pm SEM, and $P$ values below 0.05 were considered statistically significant.

\section{Results}

3.1. Cytotoxicity of Various Fractions. n-Hexane, $\mathrm{CH}_{2} \mathrm{Cl}_{2}$, EtOAc, EtOH, and EtOH/ $\mathrm{H}_{2} \mathrm{O}(1: 1)$ extracts of $A$. turanica were examined for cytotoxic potential on K562, HL-60, and normal cells (J774). Cells were incubated at $37^{\circ} \mathrm{C}$ and $5 \% \mathrm{CO}_{2}$ with various concentrations of the extract $(0-200 \mu \mathrm{g} / \mathrm{mL})$ for $48 \mathrm{~h}$. Results demonstrated that extracts decreased cell viability in a concentration-dependent manner (Figure 2). Among all the samples, $\mathrm{CH}_{2} \mathrm{Cl}_{2}$ extract demonstrated the most cytotoxic effects on cancer cells but limited adverse effect on normal cells. $\mathrm{IC}_{50}$ values $(\mu \mathrm{g} / \mathrm{mL})$ for different extracts of $A$. turanica in HL-60 and K562 cells are presented in Table 1.

3.2. Apoptosis Induction by $\mathrm{CH}_{2} \mathrm{Cl}_{2}$ Fraction. Apoptosis in K562 and HL-60 cell lines was detected with flow cytometry using PI staining test. Cells incubated with various concentrations $(0,25,50$ and $100 \mu \mathrm{g} / \mathrm{mL})$ of $\mathrm{CH}_{2} \mathrm{Cl}_{2}$ extract of $A$. turanica for $48 \mathrm{~h}$. Sub-G1 peak of treated cells in flow cytometry histograms compared to that (Sub-G1 peak) of untreated control cells revealed the induction of apoptosis in treated cells (Figure 3).

3.3. Western Blotting with HL-60 and K562 Cells. The cleavage of $116 \mathrm{kDa}$ PARP-1 to 89 and $24 \mathrm{kDa}$ fragments was used as an indicator of apoptosis. In HL-60 cells, PARP-1 was cleaved clearly to the $89 \mathrm{kDa}$ and $24 \mathrm{kDa}$ fragments after treatment with $\mathrm{CH}_{2} \mathrm{Cl}_{2}$ extract $(25,50$ and $100 \mu \mathrm{g} / \mathrm{mL})$ after $48 \mathrm{~h}$ (Figure 4). Bax proteins possess a crucial function in controlling cytochrome $\mathrm{c}$ release and apoptosis initiation via the mitochondrial pathway. $\mathrm{CH}_{2} \mathrm{Cl}_{2}$ extract $(25,50$ and $100 \mu \mathrm{g} / \mathrm{mL}$ ) could not change the level of Bax protein in both cells (Figure 4).
TABLE 1: $\mathrm{IC}_{50}$ values $(\mu \mathrm{g} / \mathrm{mL})$ for different extracts of $A$. turanica in HL-60 and K562 cell lines.

\begin{tabular}{lccccc}
\hline \multirow{2}{*}{ Cell line } & \multicolumn{5}{c}{ Fractions } \\
& $\mathrm{CH}_{2} \mathrm{CI}_{2}$ & $n$-Hexane & EtOAc & EtOH & EtOH/H $\mathrm{H}_{2} \mathrm{O}(1: 1)$ \\
\hline $\mathrm{K} 562$ & 104.2 & 234.5 & 433.1 & $>450$ & $>450$ \\
$\mathrm{HL}-60$ & 68.83 & $>450$ & 373.7 & $>450$ & $>450$ \\
\hline
\end{tabular}

\section{Discussion}

Strong evidence supports the critical role of apoptosis in the pathology of many diseases including cancer. Thus, pharmacological modulation of apoptosis is likely to be the main strategy for searching for efficient anticancer therapeutics [21].

The result of the present study supports the cytotoxic and apoptotic activity of $\mathrm{CH}_{2} \mathrm{Cl}_{2}$ extract of $A$. turanica when compared with other extracts obtained from the plant on two human leukemic cancer cell lines (K562 and HL-60).

Using $n$-hexane, $\mathrm{CH}_{2} \mathrm{Cl}_{2}$, EtOAc, EtOH, and EtOH/ $\mathrm{H}_{2} \mathrm{O}$ (1:1) solvents for extraction would afford different fractions extracts that contain the different groups of phytochemicals corresponding to the various polarity of the extractant [22]. Comparison of the results obtained with different extracts of the A. turanica confirmed the presence of potent non/semipolar phytochemicals in $\mathrm{CH}_{2} \mathrm{Cl}_{2}$ extract of the plant.

Apoptosis induction was validated using PI staining of fragmented DNA and western blot analysis of the proteins involved in programmed cell death pathway. PARP cleavage as an important indicator for apoptosis induction was consistent with other results obtained in this study. The unchanged level of Bax protein in K562 cells may reject the role of mitochondria in the apoptosis pathway. Full analysis of the proteins involved in the intrinsic pathway helps to recognize the role of the extract in apoptosis induction in cells.

Death receptor and mitochondria initiated apoptosis recruit caspases as the crucial enzyme in cell death. Caspase 8 and caspase 9 activation merged to caspase 3 stimulation, which leads to changes in the activity of some of the important enzymes involved in DNA repair. Cleavage of PARP is one of the examples of enzyme inactivation in apoptosis, which leads to unrepaired single-strand DNA breaks that accumulate in the absence of PARP activity [23].

The overcome of proapoptotic proteins like Bax to antiapoptotic proteins, located on the outer layer of the mitochondria, opens pores on the surface of the mitochondria leading to the release of cytochrome c, apoptosome formation, and caspase activation [24].

Due to some intrinsic differences, the cytotoxic results on HL-60 and K562 cells used in this study were different. The absence of the Fas/CD95/APO-1 receptor in K562 cells may be the main reason for lower $\mathrm{IC}_{50} \mathrm{~s}$ in this cell line [25]. Accordingly, apoptosis was induced in lesser extent in apoptosis-resistant K562 cells when compared with apoptosisproficient HL-60 cells. Since the role of mitochondria in the apoptosis-induction of the plant has not been proven, 


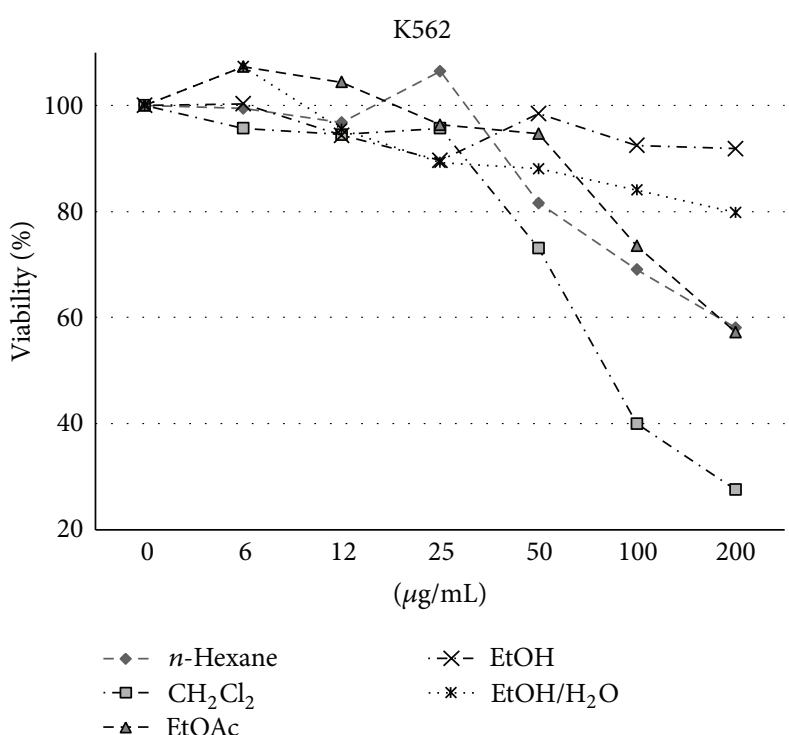

(a)

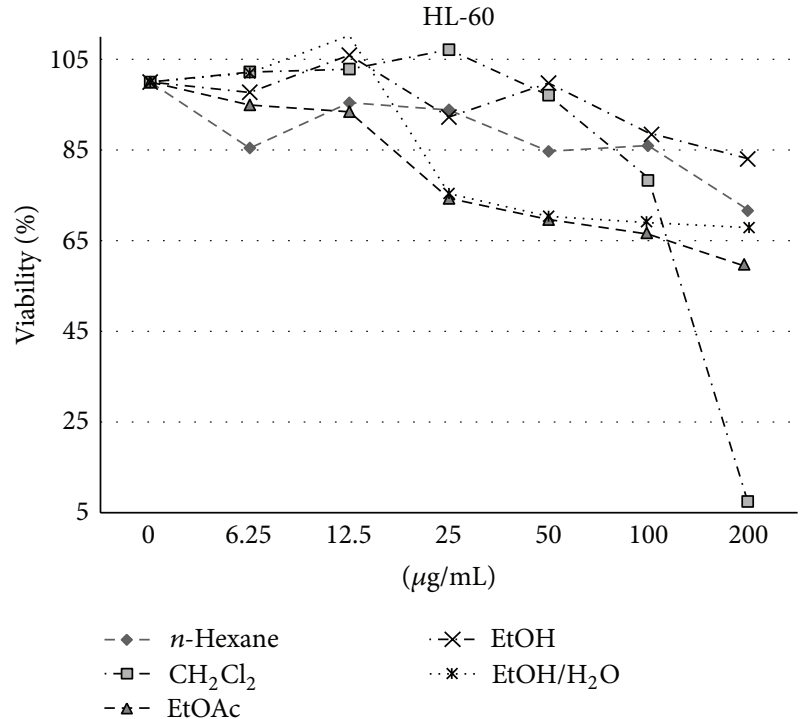

(b)

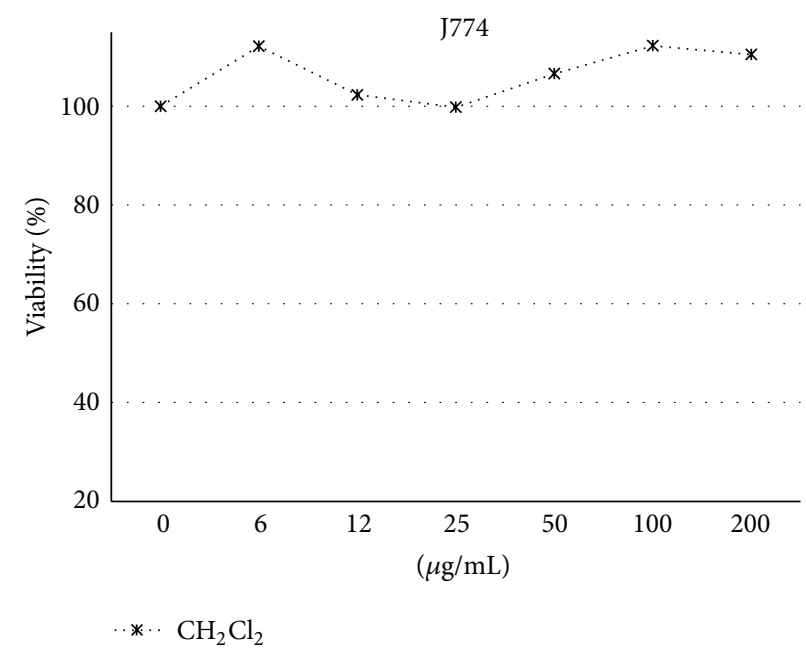

(c)

Figure 2: The dose-dependent effects of $n$-hexane, $\mathrm{CH}_{2} \mathrm{Cl}_{2}$, EtOAc, EtOH, and EtOH/H2O (1:1) extracts on the growth of K562 and HL-60 cells and normal J774 cells. All extracts exhibited cytotoxic activity against apoptosis-proficient HL-60 and apoptosis-resistant K562 cells, with $\mathrm{IC}_{50}$ values ranging from 68.83 to $>450 \mu \mathrm{g} / \mathrm{mL}$ and with much less cytotoxic effects on normal J774 cells. Values were mean \pm SEM of at least three independent experiments, each in triplicates.

interaction of the extract with death receptors other than the Fas/CD95/APO-1 receptor in K562 cells has been speculated.

Plants serve as the important part of the antitumor regimen both in conventional and alternative medicine. Many plants of the genus Artemisia have been reported to possess promising effects in research also in treating cancer [26, 27].

A cytotoxic evaluation of the isolated dimeric guaianolides from $A$. anomala showed significant inhibitory effects against the cell growth of BGC-823 tumor cell lines [28]. Two new eudesmane sesquiterpenoids from the same species exhibited cytotoxicity against HCT-8 and A549 cell lines [29]. 5/7-fused bicyclic guaianolides isolated from A. myriantha and $A$. absinthium are classified in one of the major categories of $\alpha$-methylene- $\gamma$-lactones with anticancer potential [30].
A naturally occurring flavonoid, eupatilin, isolated from $A$. princeps inhibited the growth of human endometrial cancer cells via G2/M phase cell cycle arrest [31]. RXF-393 renal cancer cell line displayed high sensibility to the organic extract from the leaves of $A$. verlotiorum, which induced a significant dose-dependent increase in the lipid peroxidation [32]. Drimartol A, a sesquiterpene coumarin ether, and two other new sesquiterpenes could efficiently induce apoptosis of a human lung cancer cell line (95-D) through the mitochondrialdependent pathway. The compounds were isolated from the cultured hairy roots of $A$. annua [33-35]. Isoscopoletin from $A$. argyi and artemisinin from $A$. annua have shown great cytotoxicity against lung and colon cancers [35]. A sesquiterpene lactone purified from $A$. diffusa inhibited spontaneous 

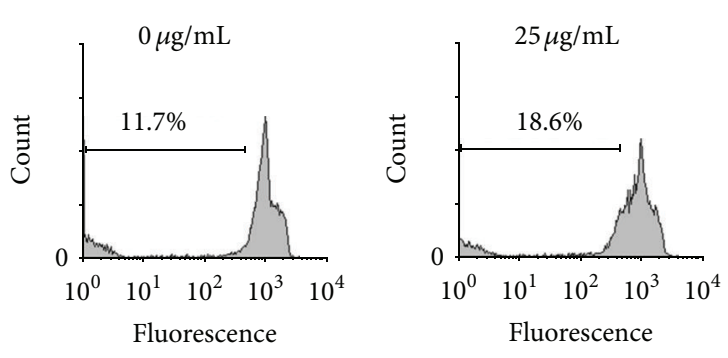

HL-60
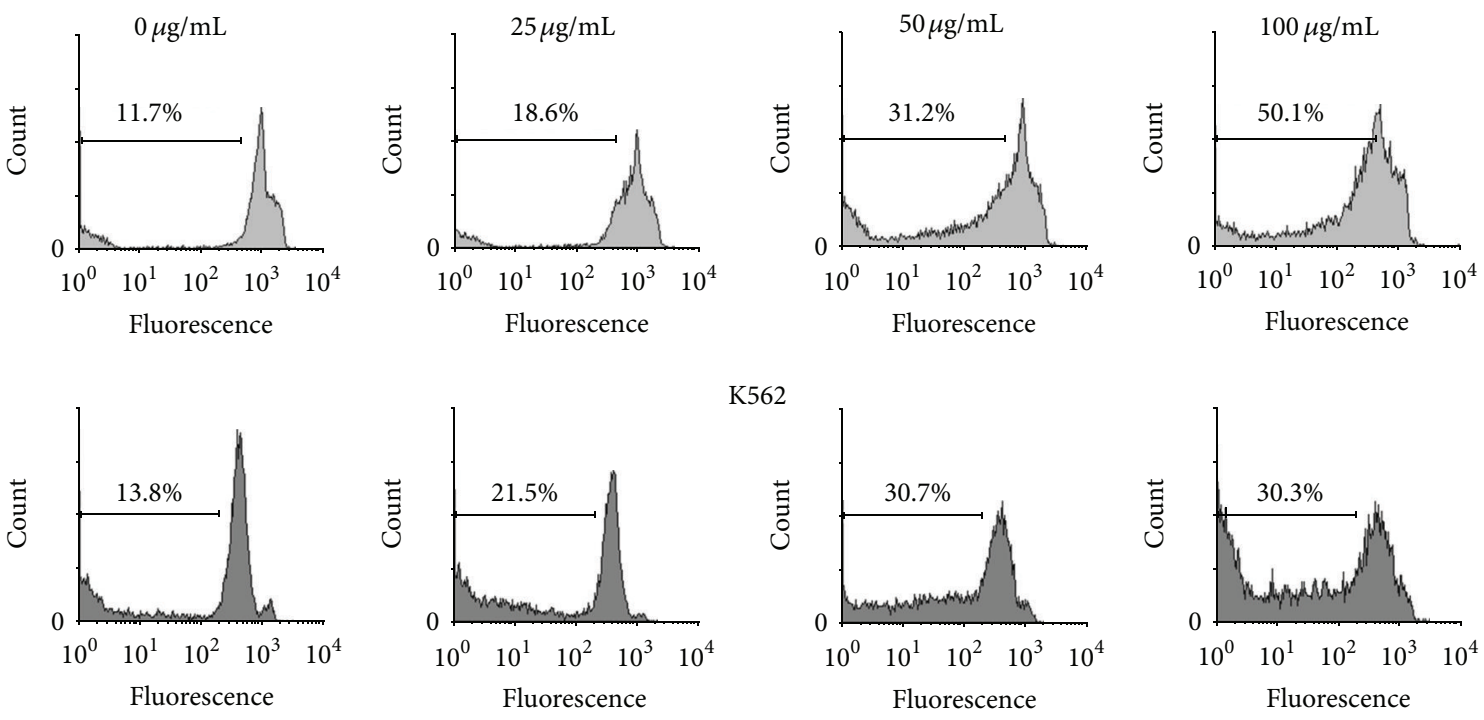

Figure 3: PI staining and flow cytometry analysis of $\mathrm{CH}_{2} \mathrm{Cl}_{2}$ extract $(0,25,50$, and $100 \mu \mathrm{g} / \mathrm{mL})$ induced apoptosis in $\mathrm{K} 562$ and $\mathrm{HL}-60$ cells.



FIgURE 4: Proteolytic cleavage of poly(ADP-ribose) polymerase (PARP) in HL-60 cells and level of Bax protein in HL-60 and K562 cells after $48 \mathrm{~h}$ exposure to $\mathrm{CH}_{2} \mathrm{Cl}_{2}$ extract of $A$. turanica $(25,50$ and $100 \mu \mathrm{g} / \mathrm{mL}) . \beta$-Actin was used as a loading control. All Western blots were representative of 3 independent experiments.

mouse mammary tumor growth in vivo [36]. The essential oil of $A$. capillaris is believed to be a good resource for searching new drugs, especially anticancer drugs because of its ability to induce apoptosis in human oral cancer cells [37].

The biological evaluation of the whole plant is provided to assess the synergistic and antagonistic interactions of mixture of phytochemicals existing in the extract [38].

Taken together, cytotoxicity and DNA fragmentation along with cleavage of PARP confirmed the apoptotic activity of the $\mathrm{CH}_{2} \mathrm{Cl}_{2}$ extract of $A$. turanica. These results indicated the presence of non/semipolar nature of the phytochemical responsible for the observed effects. Further analytical experiments on $\mathrm{CH}_{2} \mathrm{Cl}_{2}$ extract of $A$. turanica and structure elucidation should be performed to recognize the pure component responsible for the cytotoxic activity of the plant.

\section{Conflict of Interests}

The authors declare that there is no conflict of interests regarding the publication of this paper.

\section{Acknowledgments}

The authors would like to thank Mr. M. Malaekeh for his assistance in flow cytometry. This work was supported by
Grants (no. 910238) from Research Affairs of Mashhad University of Medical Sciences as a part of Pharm. D. thesis.

\section{References}

[1] W. L. W. Hsiao and L. Liu, "The role of traditional Chinese herbal medicines in cancer therapy from TCM theory to mechanistic insights," Planta Medica, vol. 76, no. 11, pp. 1118-1131, 2010.

[2] T. Efferth, H. Dunstan, A. Sauerbrey, H. Miyachi, and C. R. Chitambar, "The anti-malarial artesunate is also active against cancer," International Journal of Oncology, vol. 18, no. 4, pp. 767-773, 2001.

[3] E. Choi, H. Park, J. Lee, and G. Kim, "Anticancer, antiobesity, and anti-inflammatory activity of Artemisia species in vitro," Journal of Traditional Chinese Medicine, vol. 33, pp. 92-97, 2013.

[4] S. Z. Taghizadeh Rabe, M. Mahmoudi, A. Ahi, and S. A. Emami, "Antiproliferative effects of extracts from Iranian Artemisia species on cancer cell lines," Pharmaceutical Biology, vol. 49, no. 9, pp. 962-969, 2011.

[5] A. S. Tin, S. N. Sundar, K. Q. Tran, A. H. Park, K. M. Poindexter, and G. L. Firestone, "Antiproliferative effects of artemisinin on human breast cancer cells requires the downregulated expression of the E2F1 transcription factor and loss of E2F1-target cell cycle genes," Anti-Cancer Drugs, vol. 23, no. 4, pp. 370-379, 2012.

[6] J. G. Lee, J. H. Kim, J. H. Ahn, K. T. Lee, N. I. Baek, and J. H. Choi, "Jaceosidin, isolated from dietary mugwort (Artemisia princeps), induces $\mathrm{G} 2 / \mathrm{M}$ cell cycle arrest byinactivating cdc25Ccdc2 via ATM-Chk1/2 activation," Food and Chemical Toxicology, vol. 55, pp. 214-221, 2013.

[7] E. Y. Park, K. W. Lee, H. W. Lee et al., “The ethanol extract from Artemisia princeps Pampanini induces p53-mediated G1 phase arrest in A172 human neuroblastoma cells," Journal of Medicinal Food, vol. 11, no. 2, pp. 237-245, 2008.

[8] M. Mucciarelli and M. Maffei, "Introduction of the genus," in Artemisia, C. W. Wright, Ed., Taylor and Francis, London, UK, 2002. 
[9] V. Mozaffarian, "Flora of Iran," in Compositae (Anthemideae \& Ehinopeae), no. 59, pp. 199-261, Research Institute of Forest and Rangelands, Tehran, 2008 (Persian).

[10] S. A. Emami and F. Aghazari, Les Phanerogames Endemiques De La Flore D'Iran, Publications de I'Université de Téhéran des Sciences Médicales, Téhéran, Iran, 2011.

[11] R. X. Tan, H. Q. Tang, J. Hu, and B. Shuai, "Lignans and sesquiterpene lactones from Artemisia sieversiana and Inula racemosa," Phytochemistry, vol. 49, no. 1, pp. 157-161, 1998.

[12] K. S. Bora and A. Sharma, "The genus Artemisia: a comprehensive review," Pharmaceutical Biology, vol. 49, no. 1, pp. 101-109, 2011.

[13] V. Mozaffarian, A Dictionary of Iranian Plant Names, Farhang Moaser, Tehran, Iran, 1998 (Persian).

[14] M. Ramezani, B. S. Fazli-Bazzaz, F. Saghafi-Khadem, and A. Dabaghian, "Antimicrobial activity of four Artemisiaspecies of Iran," Fitoterapia, vol. 75, no. 2, pp. 201-203, 2004.

[15] A. Firouznia, M. T. Akbari, A. Rustaiyan, S. Masoudi, M. Bigdeli, and M. Tabatabaei-Anaraki, "Composition of the essential oils of Artemisia turanica Krasch., Helichrysum oocephalum Boiss. and Centaurea ispahanica Boiss. three asteraceae herbs growing wild in Iran," Journal of Essential Oil-Bearing Plants, vol. 10, no. 2, pp. 88-93, 2007.

[16] H. Nahrevanian, F. Aboufazeli, S. M. Kazemi, R. Hajihosseini, and S. Naeimi, "Phytochemical evaluation and antimalarial effects of artemisia turanica herbal extracts as an iranian flora on Plasmodium berghei in vivo," Journal of Natural Remedies, vol. 11, no. 2, pp. 167-176, 2011.

[17] S. A. Emami, S. Z. T. Rabe, A. Ahi, and M. Mahmoudi, "Inhibitory activity of eleven Artemisia species from Iran against Leishmania major parasites," Iranian Journal of Basic Medical Sciences, vol. 15, no. 2, pp. 807-811, 2012.

[18] M. Taherkhani, A. Rustaiyan, H. Nahrevanian, S. Naeimi, and T. Taherkhani, "Comparison of antimalarial activity of Artemisia turanica extract with current drugs in vivo," Journal of Vector Borne Diseases, vol. 50, pp. 51-56, 2013.

[19] S. A. Emami, N. Vahdati-Mashhadian, R. Vosough, and M. B. Oghazian, "The anticancer activity of five species of Artemisia on Hep2 and HepG2 cell lines," Pharmacologyonline, vol. 3, pp. 327-339, 2009.

[20] J. O’Brien, I. Wilson, T. Orton, and F. Pognan, "Investigation of the Alamar Blue (resazurin) fluorescent dye for the assessment of mammalian cell cytotoxicity," European Journal of Biochemistry, vol. 267, no. 17, pp. 5421-5426, 2000.

[21] D. Hanahan and R. A. Weinberg, "The hallmarks of cancer," Cell, vol. 100, no. 1, pp. 57-70, 2000.

[22] A. Mälkiä, L. Murtomäki, A. Urtti, and K. Kontturi, "Drug permeation in biomembranes: in vitro and in silico prediction and influence of physicochemical properties," European Journal of Pharmaceutical Sciences, vol. 23, no. 1, pp. 13-47, 2004.

[23] P. Kreuzaler and C. J. Watson, "Killing a cancer: what are the alternatives?" Nature Reviews. Cancer, vol. 11, no. 6, pp. 411-424, 2012.

[24] P. M. Peixoto, L. M. Dejean, and K. W. Kinnally, “The therapeutic potential of mitochondrial channels in cancer, ischemiareperfusion injury, and neurodegeneration," Mitochondrion, vol. 12, no. 1, pp. 14-23, 2012.

[25] R. Munker and M. Andreeff, "Induction of death (CD95/FAS), activation and adhesion (CD54) molecules on blast cells of acute myelogenous leukemias by TNF- $\alpha$ and IFN- $\gamma$," Cytokines and Molecular Therapy, vol. 2, no. 3, pp. 147-160, 1996.
[26] G. L. Firestone and S. N. Sundar, "Anticancer activities of artemisinin and its bioactive derivatives," Expert Reviews in Molecular Medicine, vol. 11, p. 32, 2009.

[27] T. Efferth, "Willmar Schwabe Award 2006: antiplasmodial and antitumor activity of artemisinin-from bench to bedside," Planta Medica, vol. 73, no. 4, pp. 299-309, 2007.

[28] K. Zan, X. Y. Chai, X. Q. Chen et al., "Artanomadimers A-F: six new dimeric guaianolides from Artemisia anomala," Tetrahedron, vol. 68, pp. 5060-5065, 2012.

[29] K. Zan, X. Q. Chen, X. Y. Chai et al., "Two new cytotoxic eudesmane sesquiterpenoids from Artemisia anomala," Phytochemistry Letters, vol. 5, no. 2, pp. 313-315, 2012.

[30] A. Janecka, A. Wyrebska, K. Gach, J. Fichna, and T. Janecki, "Natural and synthetic $\alpha$-methylenelactones and $\alpha$-methylenelactams with anticancer potential," Drug Discovery Today, vol. 17, pp. 561-572, 2012.

[31] J. H. Cho, J. G. Lee, Y. I. Yang et al., "Eupatilin, a dietary flavonoid, induces G2/M cell cycle arrest in human endometrial cancer cells," Food and Chemical Toxicology, vol. 49, no. 8, pp. 17371744, 2011.

[32] C. Marx, G. B. Kayser, D. P. Schunemann, A. Regner, A. B. da Rocha, and I. Grivicich, "Cytotoxic effect and oxidative damage of organic extract from Artemisia verlotiorum in human cancer cell lines," Latin American Journal of Pharmacy, vol. 29, no. 7, pp. 1061-1066, 2010 (Portuguese).

[33] D. D. Zhai, K. Supaibulwatana, and J. J. Zhong, "Inhibition of tumor cell proliferation and induction of apoptosis in 95-D lung cancer cells by Drimartol A from hairy root cultures of Artemisia annua," Latin American Journal of Pharmacy, vol. 29, no. 7, pp. 1159-1165, 2010.

[34] D. D. Zhai, K. Supaibulwatana, and J. J. Zhong, "Inhibition of tumor cell proliferation and induction of apoptosis in human lung carcinoma 95-D cells by a new sesquiterpene from hairy root cultures of Artemisia annua," Phytomedicine, vol. 17, no. 11, pp. 856-861, 2010.

[35] D. D. Zhai, H. Z. Jin, and J. J. Zhong, "A new sesquiterpene from hairy root culture of Artemisia annua," Chinese Chemical Letters, vol. 21, no. 5, pp. 590-592, 2010.

[36] S. Noori, M. Taghikhani, Z. M. Hassan, A. Allameha, and A. Mostafaei, "Tehranolide molecule modulates the immune response, reduce regulatory $\mathrm{T}$ cell and inhibits tumor growth in vivo," Molecular Immunology, vol. 47, no. 7-8, pp. 1579-1584, 2010.

[37] J. D. Cha, S. E. Moon, H. Y. Kim, I. H. Cha, and K. Y. Lee, "Essential oil of artemisia capillaris induces apoptosis in KB cells via mitochondrial stress and caspase activation mediated by MAPK-stimulated signaling pathway," Journal of Food Science, vol. 74, no. 9, pp. 75-81, 2009.

[38] W. M. Bandaranayake, "Quality control, screening, toxicity, and regulation of herbal drugs," in Modern Phytomedicine: Turning Medicinal Plants into Drugs, I. Ahmad, F. Aqil, and M. Owais, Eds., pp. 25-58, Wiley-VCH \& Co. KGaA, Weinheim, Germany, 2006. 

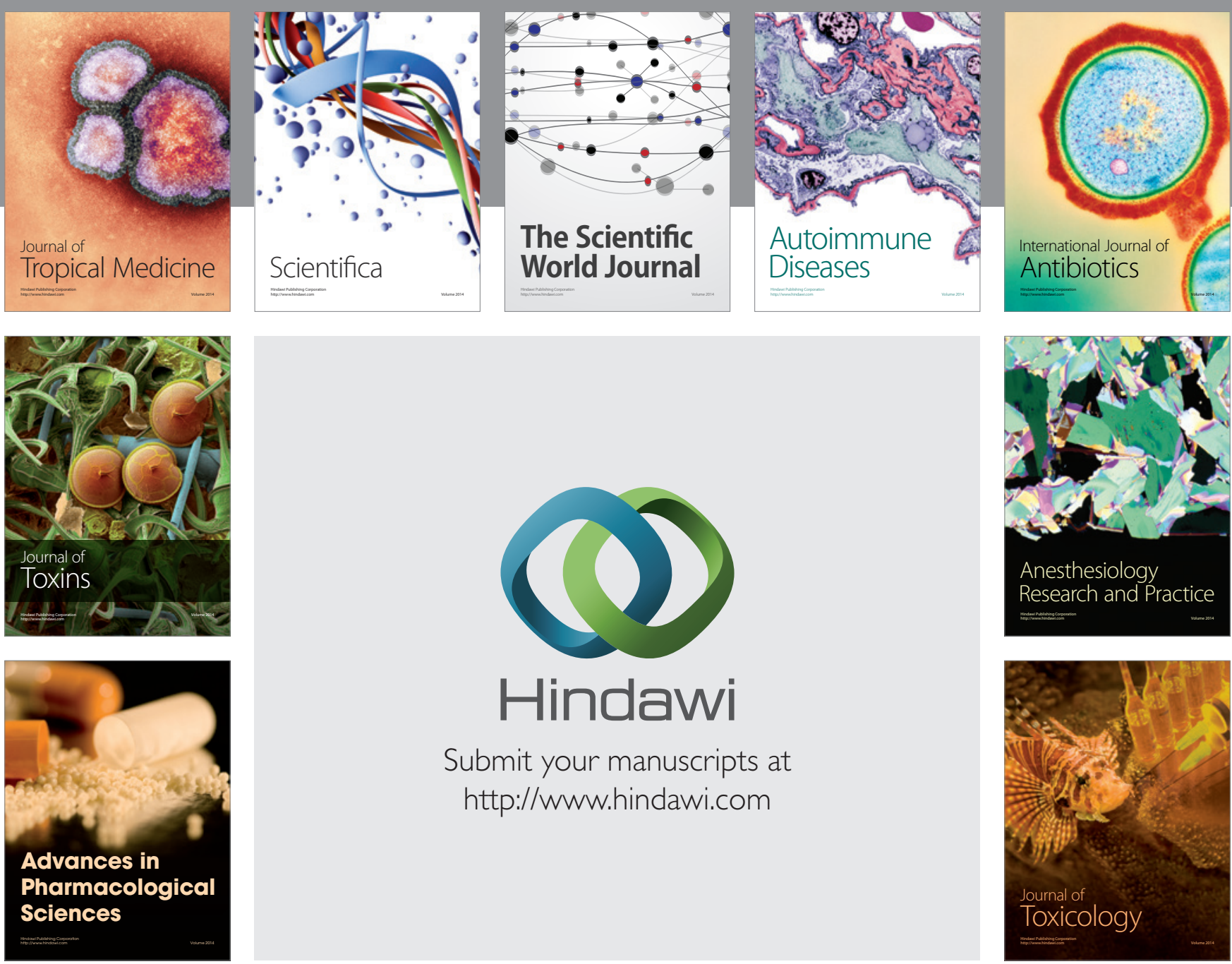

\section{Hindawi}

Submit your manuscripts at

http://www.hindawi.com
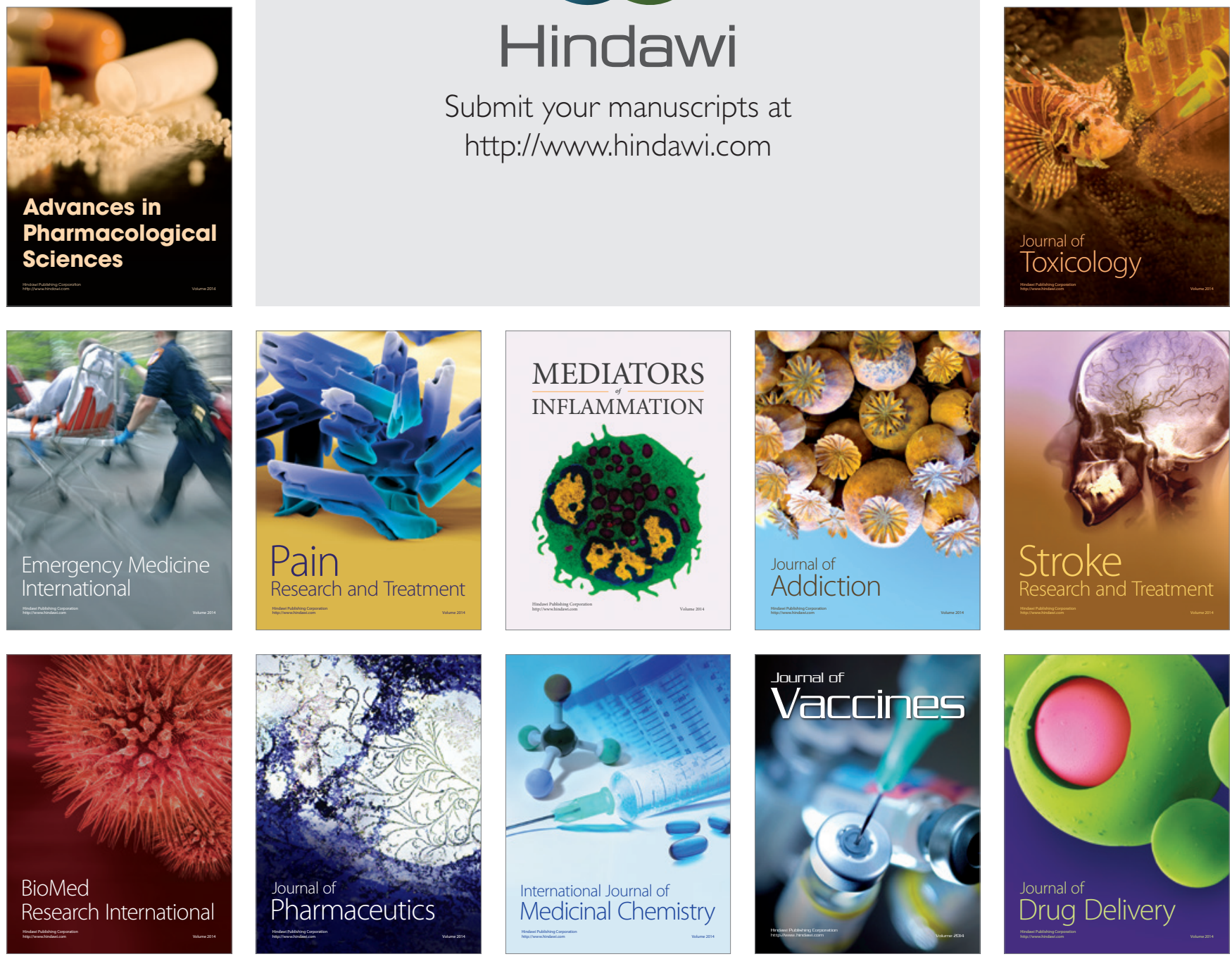